\title{
Toxicologic, hypoglycaemic and hypolipidemic effects of ethanolic and ether extracts of Commiphora molmol from Saudi Arabia.
}

\author{
Sawsan A Omer ${ }^{1 *}$, Amal M Al-Dogmi ${ }^{1,2}$ \\ ${ }^{1}$ Department of Zoology, College of Science, King Saud University, University Centre for Women Students, Riyadh, \\ Saudi Arabia \\ ${ }^{2}$ Department of Biology, College of Science, Jouf University, Jouf, P.O. Box 2014, Saudi Arabia
}

\begin{abstract}
Ether as well as ethanol extracts of Commiphora molmol administered orally to 42 rats at a dose rate of 200,400 and $600 \mathrm{mg} / \mathrm{kg}$ body weight/d for 2 weeks were toxic to laboratory rats. Group 1 was the control which was fed regular diet without the plant extract. Groups 2,4 and 6 were fed ethanol extract of $C$. molmol at a dose rate of 200,400 and $600 \mathrm{mg} / \mathrm{kg} / \mathrm{body}$ weight/d respectively. Groups 3,5 and 7 were fed ether extract of $C . \mathrm{molmol}$ at a dose rate of $200,400,600 \mathrm{mg} / \mathrm{kg} / \mathrm{body}$ weight $/ \mathrm{d}$ respectively. The toxic effects were exhibited in all groups by a significant decrease $(\mathbf{p}<0.05)$ in the body weights of the experimental rats compared to those weights of the control rats. Experimental animals showed marked depression, abdominal pain, and dyspnoea at their late stages. Haematological changes in rats fed both ether and ethanol extracts of the plant were indicated by significant decrease $(p<0.05)$ in the $R B C$ count as well as in the haemoglobin concentrations while there was significant increase $(\mathbf{p}<0.05)$ in the WBC counts. Rats which fed ether extract showed significant decrease in glucose in all groups, cholesterol and triglycerides and a significance increase in bilirubin concentration in experimental animals which fed 400 and $600 \mathrm{mg} / \mathrm{body}$ weight/d. Histological changes in experimental rats were observed in the form of fatty change and necrosis of hepatocytes, renal tubular cell degeneration, and shrinkage of the glomeruli.
\end{abstract}

Keywords: Commiphora molmol, Toxicity, Hypolepidemia, Hypoglycaemia.

Accepted on April 18, 2018

\section{Introduction}

Among genera of the family Burseraceae is the genus Commiphora which includes over 700 species. These species are native that naturally occur in the seasonally dry tropics of Africa, Arabia and India [1,2]. The name Commiphora originates from the Greek words kommi (meaning 'gum') and phero (meaning 'to bear'). Commiphora myrrha (Nees) Engl. is a small tree or a large shrub which found in the dry and arid regions of Ethiopia and Somalia and to some extent in northern Kenya [3]. Myrrh, a yellow fragrant oleo-gum resin, is a famous traditional herb, which is derived from the damaged bark of Commiphora spp. [4].

Myrrh has many medicinal powers and has been used to treat various diseases, such as amenorrhea, ache, dysmenorhhea, tumors, fever, stomach complaints (for example, for stimulating the appetite and the flow of digestive juices), diseases of gall bladder, chest ailments, snake and scorpion bites, and skin infections in India, China, Greece and Babylon $[5,6]$. It is also used in traditional medicine as antiseptic, carminative, anti-inflammatory, tonic in dyspepsia, emmenagogue, remedy for spongy gums, aphthous stomatitis and indolent ulcer [7,8].

Previous investigations have revealed that myrrh contains about 2 to $8 \%$ essential oil (myrrhol), 23 to $40 \%$ resin (myrrhin), 40 to $60 \%$ gum, and 10 to $25 \%$ bitter principles. Essential oil of myrrh was reported that the furanosesquiterpenoids were rich in the exudates, and around 20 different compounds of this type have been isolated and identified [9-11]. Phytochemicals present in this plant investigated previously and resulted in a series of metabolites including terpenoids, steroids, flavonoids, lignans, carbohydrates, sesquiterpenes, aldyhydes, euginol, resin commophoric acids, volatile and essential oils, salts and proteins and long chain aliphatic alcohol derivatives isolated and identified from Commiphora species [5,12-15]. These secondary metabolites and crude extracts of the Commiphora species exhibited diverse biological activities, such as cytotoxic, anaesthetic, anti-inflammatory, and antimicrobial effects [16-20]. The antimicrobial activity of plant oils and extracts has formed the basis of many applications, including raw and processed food preservation, pharmaceuticals, alternative medicine and natural therapies [21-23]. The use of 
Commiphora extracts in treating cancer and viral infections has also been attempted and in recent years [24-27].

Despite the fact that most of the previous studies concentrated on the positive aspects of using Commiphora extracts, only few have pointed out the toxic effect of Commiphora extracts on laboratory animals and on small ruminants [24,28].

The aim of the present study is to determine the toxicity that develops as a result of feeding experimental animals different concentrations of the oleo-gum resin extracts of Commiphora molmol and evaluate the haematological changes, biochemical changes, hepatorenal alterations.

\section{Materials and Methods}

Oleo-gum resin (Commiphora molmol) was obtained from herbalists at the local market in the City of Riyadh. The identity of the plant was identified by a Botanist from the Department of Botany and Microbiology, College of Science, King Saud University. The oelo-gum resin of C. molmol was extracted using ethanol and ether extraction methods and the extract was fed orally using gastric gavage to experimental rats.

\section{Experimental animals}

A total of 42 male Wistar albino rats were obtained from the Animal House at the College of Pharmacy, King Saud University and kept at animal facility at the Department of Zoology. Experimental animals were housed randomly in cages

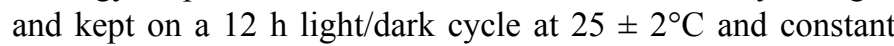
humidity. Food and water were provided ad libitum.

Experimental animals were fed daily the recommended dose from each of the plant extract using tube feeding (gastric gavage).

All animals were kept for one week prior to experimentation for acclimation. The rats were divided in to 7 groups each had 6 rats. Group 1 was the control which was fed regular diet without the plant extract. Groups 2, 4 and 6 were fed ethanol extract of C. molmol at a dose of 200, 400 and $600 \mathrm{mg} / \mathrm{kg}$ body weight/day respectively. Groups 3, 5 and 7 were fed ether extract of $C$. molmol at a dose rate of $200,400,600 \mathrm{mg} / \mathrm{kg}$ body weight/d respectively for 2 weeks. Body weights of the experimental animals were measured at the start and at the end of the experiment. At the end of the experiment all animals in each group were scarified for studying the alterations in the haematological and biochemical profiles. Tissues from the livers, kidneys were also collected for studying histological changes compared to the control animals.

\section{Haematological analyses}

For handling of animal, isoflurane (halogenated ether) was used to collect blood samples at the end of the experiment from the retro-orbital plexus using sterile glass capillary tubes. Two sets of tubes were used one with anticoagulant (EDTA) for haematological tests and other one without anticoagulant for biochemical tests. The haematology analyzer CCP Beckman counter (Becman Coulter, California, USA) was used to determine complete haemogram including red blood corpuscular Counts (RBCs), Haemoglobin (HB) concentration, total White Blood Cell (WBCs) and differential counts, Packed Cell Volume (PCV) and Platelets counts. Mean Corpuscular Volume (MCV) and Mean Corpuscular Haemoglobin Concentration (MCHC) were calculated from the erythrocytes counts as well as PCV and haemoglobin values.

\section{Biochemical analyses}

Serum samples were collected at the end of the experiment were analyzed for the activities of Lactate Dehydrogenase (LDH), Alkaline Phosphotase (ALP), Alanine Transmainase (ALT) and concentrations of cholesterol, total bilirubin, glucose, triglycerides, Albumin, Calcium, potassium and creatinine using biochemistry analyzer BSA3000 (Diagnostic Instruments Manufacture, SFR1, France).

\section{Histological investigations}

At the end of the experiment all animals in all groups were sacrificed using an overdose of isoflurane for tissue collection. Samples of kidney and liver were fixed in $10 \%$ Neutral Buffered Formalin (NBF) for $2 \mathrm{~d}$, processed, blocked into paraffin blocks, cut into $5 \mu \mathrm{m}$ sections and stained with haematoxylin and eosin for histological investigations.

\section{Statistical analyses}

Statistical analysis was performed employing the computer software SSPS (version 18) and the student's t-test to evaluate the differences between the control and the test groups.

\section{Results}

The effect on the body weights of orally administered ether and ethanol extracts of Commiphora molmol at a dose rate of 200, $400,600 \mathrm{mg} / \mathrm{kg}$ body weight/d for 2 weeks was shown in Table 1. Body weights of the control animals has increased significantly $(\mathrm{p}<0.001)$ during the 2 weeks experiment. The body weights of the experimental animals, however, showed significant decrease $(\mathrm{p}<0.01-0.001)$ in body weights in the majority of the experimental animals compared to the body weights of those animals at the start of the experiment. Only animals in groups 2 and 4 showed significant increase in their body weights unlike other experimental animals in different groups.

Table 1. Changes in the body weights of rats given 200, 400 and 600 $\mathrm{mg} / \mathrm{kg}$ body weight ether and ethanol extracts of Commiphora molmol Oleo-gum resin.

\begin{tabular}{|c|c|c|c|c|c|}
\hline Group & Extract & $\begin{array}{l}\text { Start } \\
\text { experiment }\end{array}$ & of & First week & Second week \\
\hline \multirow{2}{*}{$200 \mathrm{mg} / \mathrm{kg}$} & Ether & $268.00 \pm 0.58$ & & $239.67 \pm 11.30$ & $242.67 \pm 19.10^{* *}$ \\
\hline & Ethanol & $265.83 \pm 1.49$ & & $290.83 \pm 1.38$ & $274.00 \pm 1.61^{* \star *}$ \\
\hline $400 \mathrm{mg} / \mathrm{kg}$ & Ether & $287.00 \pm 0.63$ & & $249.33 \pm 5.14$ & $201.00 \pm 2.00^{\star \star *}$ \\
\hline
\end{tabular}


Toxicologic, hypoglycaemic and hypolipidemic effects of ethanolic and ether extracts of Commiphora molmol from Saudi Arabia

\begin{tabular}{lllll}
\cline { 2 - 5 } & Ethanol & $282.33 \pm 3.68$ & $304.00 \pm 5.91$ & $303.33 \pm 3.71^{\star \star \star}$ \\
\hline $600 \mathrm{mg} / \mathrm{kg}$ & Ether & $323.67 \pm 1.52$ & $239.75 \pm 24.76$ & $236.00 \pm 34.00^{\star \star \star}$ \\
\cline { 2 - 5 } & Ethanol & $333.50 \pm 7.94$ & $361.50 \pm 2.40$ & $281.00 \pm 23.4^{\star \star \star}$ \\
\hline Control & & $308.33 \pm 15.73$ & $333.00 \pm 12.62$ & $392.00 \pm 0.58^{\star \star \star}$ \\
\hline
\end{tabular}

\begin{tabular}{|c|c|c|c|c|}
\hline Eosino & $2.5 \pm 0.5$ & $1.00 \pm 0.5^{\star \star *}$ & $2.97 \pm 1.69^{\mathrm{NS}}$ & $3.66 \pm 0.2^{\star * *}$ \\
\hline
\end{tabular}
$p<0.01 ;{ }^{* * *} 0.001$.

Data are presented as mean \pm SD; ${ }^{*}$ Significant at $p<0.05 ;{ }^{* *} p<0.01 ;{ }^{* \star *} 0.001$.

Table 2. Haematological changes in the experimental animals which were fed ether extract of Commiphora molmol oleo-gum resin.

\begin{tabular}{|c|c|c|c|c|}
\hline \multirow{2}{*}{ Ether } & \multicolumn{4}{|l|}{ Groups } \\
\hline & Control & $200 \mathrm{mg} / \mathrm{kg} \mathrm{(3)}$ & $400 \mathrm{mg} / \mathrm{kg}(5)$ & $600 \mathrm{mg} / \mathrm{kg}(7)$ \\
\hline WBC & $\begin{array}{l}15.62 \\
0.86\end{array}$ & $28.78 \pm 3.39^{* \star \star}$ & $28.52 \pm 2.32^{\star \star \star}$ & $27.02 \pm 5.09^{\star \star \star}$ \\
\hline RBC & $8.29 \pm 0.16$ & $7.16 \pm 0.36^{* * *}$ & $7.61 \pm 0.38^{* *}$ & $7.9 \pm 0.43^{\mathrm{NS}}$ \\
\hline $\begin{array}{l}\text { Haemoglobi } \\
\mathrm{n}\end{array}$ & $\begin{array}{l}15.18 \\
0.27\end{array}$ & $13.32 \pm 0.71^{\star \star \star}$ & $13.34 \pm 0.8^{* \star *}$ & $13.04 \pm 0.75^{\star \star \star}$ \\
\hline PCV & $\begin{array}{l}45.08 \\
0.74\end{array}$ & $40.18 \pm 2.38^{\star \star \star}$ & $40.98 \pm 2.42^{* *}$ & $43.26 \pm 1.76^{*}$ \\
\hline $\mathrm{MCV}$ & $54.53 \pm 1.1$ & $56.0 .7 \pm 1.17^{\star}$ & $53.82 \pm 2.42^{\mathrm{NS}}$ & $55.12 \pm 1.81^{\mathrm{NS}}$ \\
\hline $\mathrm{MCH}$ & $18.3 \pm 0.35$ & $18.55 \pm 0.42^{\mathrm{NS}}$ & $17.42 \pm 0.2^{\star \star \star}$ & $17.76 \pm 0.59^{* * *}$ \\
\hline $\mathrm{MCHC}$ & $\begin{array}{l}33.65 \\
0.52\end{array}$ & $33.17 \pm 0.44^{\mathrm{NS}}$ & $32.5 \pm 0.21^{\star \star *}$ & $32.28 \pm 0.16^{* * *}$ \\
\hline Platelets & $1323 \pm 32$ & $1312 \pm 110^{\mathrm{NS}}$ & $992 \pm 176^{\star *}$ & $1850 \pm 256^{\star * *}$ \\
\hline MPV & $6.08 \pm 0.13$ & $5.97 \pm 0.18^{\mathrm{NS}}$ & $5.8 \pm 0.08^{* *}$ & $5.76 \pm 0.07^{\star \star \star}$ \\
\hline Neut & $34.7 \pm 3.18$ & $47.57 \pm 6.23^{* *}$ & $66.22 \pm 6.88^{\star \star \star}$ & $51.64 \pm 6.46^{* * *}$ \\
\hline Lympho & $60.5 \pm 3.82$ & $48.23 \pm 6.55^{\star \star}$ & $28.86 \pm 5.65^{\star \star}$ & $44.22 \pm 6.14^{* \star *}$ \\
\hline Mono & $3.97 \pm 0.64$ & $3.78 \pm 0.49^{N S}$ & $3.14 \pm 0.44^{*}$ & $3.76 \pm 0.55^{\mathrm{NS}}$ \\
\hline
\end{tabular}

Table 3. Haematological changes in the experimental animals which were fed ethanolic extract of Commiphora molmol oleo-gum resin.

\begin{tabular}{|c|c|c|c|c|}
\hline \multirow{2}{*}{ Ethanol } & \multicolumn{4}{|l|}{ Groups } \\
\hline & Control & $200 \mathrm{mg} / \mathrm{kg}(2)$ & $400 \mathrm{mg} / \mathrm{kg}(4)$ & $600 \mathrm{mg} / \mathrm{kg}(6)$ \\
\hline WBC & $15.62 \pm 0.86$ & $21.57 \pm 2.22^{\star \star \star}$ & $20.65 \pm 3.15^{* *}$ & $20.75 \pm 3.55^{* *}$ \\
\hline RBC & $8.29 \pm 0.16$ & $7.58 \pm 0.18^{* \star *}$ & $7.92 \pm 0.28^{*}$ & $8.01 \pm 0.25^{\mathrm{NS}}$ \\
\hline Haemoglobin & $15.18 \pm 0.27$ & $13.83 \pm 0.41^{\star * *}$ & $\begin{array}{l}14.97 \\
0.49^{N S}\end{array}$ & $15.1 \pm 0.2^{\mathrm{NS}}$ \\
\hline PCV & $45.08 \pm 0.74$ & $41.65 \pm 1.0^{\star \star \star}$ & $44.3 \pm 0.96^{\mathrm{NS}}$ & $45.02 \pm 0.85^{\mathrm{NS}}$ \\
\hline MCV & $54.53 \pm 1.1$ & $55.05 \pm 0.57^{\mathrm{NS}}$ & $56.22 \pm 1.2^{*}$ & $56.4 \pm 1.28^{*}$ \\
\hline $\mathrm{MCH}$ & $18.3 \pm 0.35$ & $18.2 \pm 0.2^{\mathrm{NS}}$ & $18.88 \pm 0.33^{*}$ & $18.88 \pm 0.54^{\mathrm{NS}}$ \\
\hline $\mathrm{MCHC}$ & $33.65 \pm 0.52$ & $33.17 \pm 0.66^{\mathrm{NS}}$ & $\begin{array}{l}33.72 \\
0.69^{N S}\end{array}$ & $\begin{array}{l}33.52 \\
0.422^{\mathrm{NS}}\end{array}$ \\
\hline Platelets & $1323 \pm 32$ & $1388 \pm 133^{N S}$ & $1405 \pm 72^{*}$ & $1737 \pm 178^{* \star}$ \\
\hline MPV & $6.08 \pm 0.13$ & $5.82 \pm 0.17^{*}$ & $6.00 \pm 0.15^{\mathrm{NS}}$ & $5.9 \pm 0.18^{N S}$ \\
\hline Neut & $34.7 \pm 3.18$ & $38.30 \pm 1.79^{*}$ & $\begin{array}{l}32.93 \\
6.33^{\mathrm{NS}}\end{array}$ & $43.2 \pm 4.51^{\star \star}$ \\
\hline Lympho & $60.5 \pm 3.82$ & $55.13 \pm 2.81^{*}$ & $56.8 \pm 3.49^{N S}$ & $53.48 \pm 4.32^{*}$ \\
\hline Mono & $3.97 \pm 0.64$ & $4.88 \pm 1.06^{\mathrm{NS}}$ & $3.08 \pm 8.81^{\mathrm{NS}}$ & $3.13 \pm 0.34^{*}$ \\
\hline Eosino & $2.5 \pm 0.5$ & $3.37 \pm 1.17^{\mathrm{NS}}$ & $2.33 \pm 0.33^{\mathrm{NS}}$ & $1.33 \pm 0.33^{* *}$ \\
\hline
\end{tabular}

Data are presented as mean $\pm \mathrm{SD}$; NSNon-Significant; "Significant at $p<0.05$; ${ }^{* *} p<0.01 ;{ }^{* * *} 0.001$.

Table 4. Biochemical changes in the experimental animals which were fed ether extract of Commiphora molmol oleo-gum resin.

\begin{tabular}{|c|c|c|c|c|}
\hline \multirow{2}{*}{ Ether } & \multicolumn{4}{|l|}{ Groups } \\
\hline & Control & 200 mg/kg (3) & 400 mg/kg (5) & 600 mg/kg (7) \\
\hline Glucose & $153.5 \pm 6.77$ & $117.67 \pm 3.97^{\star \star \star}$ & $115.00 \pm 14.51^{\star * \star}$ & $106.6 \pm 15.79^{\star \star \star *}$ \\
\hline Cholesterol & $107.17 \pm 4.87$ & $86.00 \pm 6.99^{*}$ & $90.4 \pm 8.55^{\mathrm{NS}}$ & $83.00 \pm 11.82^{\mathrm{NS}}$ \\
\hline Triglycerides & $89.00 \pm 17.18$ & $48.5 \pm 3.33^{\star * *}$ & $44.6 \pm 0.93^{* * *}$ & $47.6 \pm 1.94^{* \star *}$ \\
\hline Alkaline phosphatase & $223.83 \pm 19.57$ & $217.5 \pm 36.73^{\mathrm{NS}}$ & $184.2 \pm 37.99^{*}$ & $238.2 \pm 60.31^{\mathrm{NS}}$ \\
\hline Total bilirubin & $0.50 \pm 0.13$ & $1.37 \pm 0.59^{* *}$ & $3.66 \pm 1.35^{\star * *}$ & $2.02 \pm 0.74^{\star * *}$ \\
\hline $\mathrm{LDH}$ & $671 \pm 36.25$ & $1005 \pm 265^{*}$ & $3239.4 \pm 644.68^{* \star *}$ & $1527.6 \pm 453.9^{\star * *}$ \\
\hline Calcium & $11.96 \pm 2.23$ & $11.86 \pm 2.5^{\mathrm{NS}}$ & $11.1 \pm 1.9^{\mathrm{NS}}$ & $9.99 \pm 2.1^{\mathrm{NS}}$ \\
\hline Potassium & $7.30 \pm 7.5$ & $7.40 \pm 1.7^{\mathrm{NS}}$ & $7.4 \pm 1.6^{\mathrm{NS}}$ & $7.3 \pm 1.8^{\mathrm{NS}}$ \\
\hline Creatinine & $0.4 \pm 0.1$ & $0.50 \pm 0.1^{\mathrm{NS}}$ & $0.6 \pm 0.15^{*}$ & $3.5 \pm 0.25^{* * *}$ \\
\hline Albumin & $28.87 \pm 1.26$ & $30.05 \pm 0.45^{\mathrm{NS}}$ & $32.5 \pm 3.43^{*}$ & $40.55 \pm 8.76^{\star \star}$ \\
\hline ALT & $43.67 \pm 9.4$ & $56.54 \pm 3.0^{\star *}$ & $64.76 \pm 5.6^{\star \star \star}$ & $70.2 \pm 10.3^{\star \star \star}$ \\
\hline
\end{tabular}


Data are presented as mean \pm SD; NS Non-Significant; "Significant at $p<0.05 ;{ }^{* *} p<0.01 ;{ }^{* * *} 0.001$.

Table 5. Biochemical changes in the experimental animals which were fed ethanolic extract of Commiphora molmol oleo-gum resin.

\begin{tabular}{|c|c|c|c|c|}
\hline \multirow{2}{*}{ Ethanol } & \multicolumn{4}{|l|}{ Groups } \\
\hline & Control & $200 \mathrm{mg} / \mathrm{kg}(2)$ & 400 mg/kg (4) & 600 mg/kg (6) \\
\hline Glucose & $153.5 \pm 6.77$ & $126.83 \pm 6.53^{* \star \star}$ & $139.5 \pm 6.46^{* *}$ & $138.33 \pm 6.69^{* *}$ \\
\hline Cholesterol & $107.17 \pm 4.87$ & $94 \pm 6.68^{*}$ & $82.50 \pm 4.79^{* * *}$ & $87.67 \pm 4.5^{* * *}$ \\
\hline Triglycerides & $89.00 \pm 17.18$ & $61 \pm 6.49^{\star *}$ & $53 \pm 4.18^{\star \star \star}$ & $70.17 \pm 23.8^{\star \star \star}$ \\
\hline Alkaline phosphatase & $223.83 \pm 19.57$ & $216 \pm 38.31^{\mathrm{NS}}$ & $200.67 \pm 24.49^{\text {NS }}$ & $110.4 \pm 28.29^{\mathrm{NS}}$ \\
\hline Total bilirubin & $0.50 \pm 0.13$ & $0.37 \pm 0.06^{* *}$ & $0.42 \pm 0.04^{\mathrm{NS}}$ & $1.2 \pm 0.09^{* * *}$ \\
\hline LDH & $671 \pm 36.25$ & $872.17 \pm 75.76^{* \star *}$ & $1925.5 \pm 804.57^{* * *}$ & $1272.8 \pm 247.06^{* * *}$ \\
\hline Calcium & $11.96 \pm 2.23$ & $12.11 \pm 3.2^{\mathrm{NS}}$ & $10.91 \pm 2.1^{\mathrm{NS}}$ & $9.99 \pm 1.8^{\mathrm{NS}}$ \\
\hline Potassium & $7.30 \pm 1.5$ & $7.2 \pm 2.3^{\mathrm{NS}}$ & $7.4 \pm 1.6^{\mathrm{NS}}$ & $7.3 \pm 1.8^{\mathrm{NS}}$ \\
\hline Creatinine & $0.4 \pm 0.1$ & $0.5 \pm 0.2^{\mathrm{NS}}$ & $0.6 \pm 0.15^{*}$ & $13.25 \pm 2.2^{* * *}$ \\
\hline Albumin & $28.87 \pm 1.26$ & $27.4 \pm 1.5^{\mathrm{NS}}$ & $28.5 \pm 1.36^{\mathrm{NS}}$ & $47.55 \pm 17.45^{\star}$ \\
\hline ALT & $43.67 \pm 9.4$ & $63 \pm 2.0^{* \star *}$ & $51 \pm 7.37^{\mathrm{NS}}$ & $77 \pm 7.5^{* * *}$ \\
\hline
\end{tabular}

Data are presented as mean $\pm \mathrm{SD} ;{ }^{N S}$ Non-Significant; ${ }^{*}$ Significant at $p<0.05 ;{ }^{* *} p<0.01 ;{ }^{* * *} 0.001$.

Experimental animals which were fed with the plant extract (ethanol or ether) showed marked weakness, ruffled hair, depression, abdominal pain, loose pellets, and dyspnoea particularly in the second week of the experiment. Control animals were apparently clinically normal and passing formed pellets and looked without apparent dyspnoea. Two animals died during the course of the experiment. One animal from group 5 which were given $400 \mathrm{mg} / \mathrm{kg}$ body weight/d of ether extract and the other one was from group 6 which were given $600 \mathrm{mg} / \mathrm{kg}$ body weight $/ \mathrm{d}$ of the ethanol extract of C. molmol.

Haematological changes (Table 2) in rats fed ether extract of the plant for 2 weeks were indicated by significant decrease in the RBCs, haemoglobin, haematocrit values, MCHC and platelets counts $(p<0.01-0.001)$. On the white blood cells there was a significant increase in the counts after the 2 weeks experiment $(p<0.001)$ together with an increase in the neutrophils numbers and a decrease in the lymphocytes $(p<0.01-0.001)$. There was a significant increase in the total number of eosinophil $(\mathrm{p}<0.001)$.

The haematological changes in the experimental animals which were fed ethanol extracts for 2 weeks were shown in Table 3. Experimental animals have shown significant decrease in the RBCs count, in $\mathrm{Hb}$ concentration as well as in the PCV. There was, however, a significant increase in the WBCs counts $(\mathrm{p}<0.01)$ together with an increase in the neutrophils and a decrease in the lymphocytes and the eosinophil's $(p<0.01)$.

Thrombocytes were increased in all experimental groups compared to the control group.
Biochemical changes in the animals fed different concentrations of the ether extracts of the plant were shown in Table 4. Biochemical changes were indicated by a significant decrease in the blood glucose, triglycerides $(p<0.01-0.001)$ and a significant increase in the concentrations of total bilirubin, albumin, LDH, ALT, and creatinine $(\mathrm{p}<0.01-0.001)$. There was a significant reduction in the serum cholesterol concentration in experimental animals in group 3; however the reduction in the cholesterol concentrations in groups 5 and 7 was not significant.

Biochemical changes in the animals fed different concentrations of the ethanol extracts of the plant were shown in Table 5. Biochemical changes were indicated by a significant decrease in the blood glucose, cholesterol, triglycerides $(p<0.01-0.001)$ and a significant increase in the concentrations of total bilirubin, albumin, LDH, ALT, and creatinine $(\mathrm{p}<0.01-0.001)$.

Other biochemical parameters, in all experimental groups, such as calcium, potassium and alkaline phosphatase showed no changes compared with the control group.

On post mortem the livers of the experimental animals appeared either congested with blood or yellow in colour and the degree of severity was dependent on the dose administrated orally of each plant extract (Figures 1A-1H). Kidneys appeared congested with blood and intestines showed congested blood vessels. Histopathological changes noticed in both tissues of the livers and kidneys of experimental animals which received different doss of ethanol and ether extracts of $C$. molmol showed variation in severity. The pathological changes were dependent on the dose administered with the severe lesions 
noticed in animals received $600 \mathrm{mg} / \mathrm{kg}$ body weight $/ \mathrm{d}$ of the plant extract. Moreover, histopathological changes in animals received ether extracts were more pronounced compared to those recorded from those which received the ethanol extract of the plant. Changes observed in the liver were in the form of generalized fatty vacuolations, centrilobular hepatocellular degeneration and congestion of liver sinusoids and central veins as well as inflammatory cells infiltrations particularly lymphocytic. Severe lesions were noticed in animals which received $600 \mathrm{mg} / \mathrm{kg}$ body weight/d while control animals showed no pathological changes.

Kidneys showed severe glomerular necrosis, shrinkage of glomeruli as well as lymphocytic infiltration between the distal convoluted tubules and tubular hyaline degeneration.

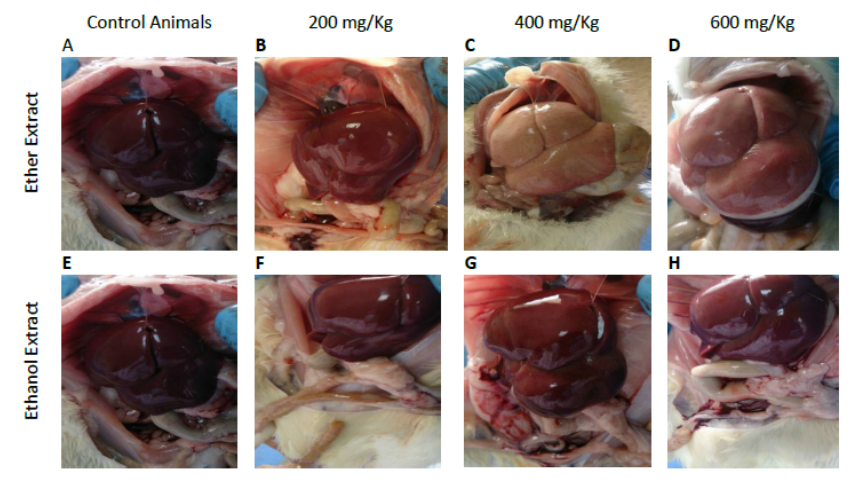

Figure 1. Livers of experimental animals exposed to ether extracts of C. myrrha. $A$ and $E$ for control animals. $B, C$ and $D$ were from animals received 200, 400 and $600 \mathrm{mg} / \mathrm{kg}$ of ether extract daily for two weeks respectively showing remarkable fatty change. $F, G$ and $H$ were from animals received 200, 400 and $600 \mathrm{mg} / \mathrm{kg}$ of ethanol extract daily for two weeks respectively exhibiting congestion and liver enlargement.

\section{Discussion}

Oleo gum resin of Commiphora spp. is widely used in Saudi Arabia and other parts of the world for the treatment of various disorders. Not much is known on the toxicity of these plants to the laboratory animals or other animal species. This study showed that the ether as well as ethanol extracts of a Commiphora molmol given orally at a dose rate of 200, 400, $600 \mathrm{mg} / \mathrm{kg}$ body weight/d for 2 weeks were toxic and even lethal to the laboratory rats. It has adversely affected the health of the experimental animals. Clinicopathological, hematological and clinical chemistry changes were indicative of the influence of plant ether and ethanolic extracts on the liver, kidneys and intestines.

There was a decrease in body weight in all groups of rats that fed ether and ethanol extracts of the plant, however, the reduction in weight was significant in the animals received ether extracts. This decrease in body weight may be due to decrease in feed intake and growth which resulted from damage to vital organs. This finding agreed with that of Omer et al. who found that $10 \%$ and $20 \%$ of Commiphora myrrha in diet caused enterohepatonephropathy and anaemia [28]. Mostafa et al. found that $C$. myrrha significantly decreased the body weight gain in obese hyperlipidaemia rats. It is probably that the intestinal lesion may have resulted in the movement of the digested food quickly through the intestine and deprived the animals from absorbing digested food hence the soft pellets.

At the end of the experiment it has been shown that, the animals which fed ether and ethanol extract of C. molmol did show significant haematological changes in the form of increase in white blood cells, platelets, MPV neutrophils and eosinophil's compared to the control and significant reduction in the RBCs, Hb, PCV and lymphocytes.

Similar findings were found by when they studied the toxic effects of orally administered aqueous extract of Abrus precatorius in mice and Wister rats [29]. They found significant decrease in Red Blood Cells (RBC) and lymphocytes and a significant increase in white blood cells and eosinophil's. The possible explanation for the increase in eosinophil may be due to adrenosteroid production as has been suggested by Pagana [30]. The decrease in Red Blood Corpuscle counts may be due to the depression in erythropoiesis in the bone marrow and possibly anaemia which result from effect of the constituents of the plant present in both the ethanolic and ether extracts. Additionally the decrease in RBC count as well as the haemoglobin may possibly be due to haemolysis or failure of erythropoietin production. It is known that various anti-nutritional substances and xenobiotic chemical like saponin and tannin cause haemolysis, nutritional mal-absorbtion and abnormal haematopoiesis [31,32]. Commiphora myrrha contains several terpenes and steroids which are known to possess cytotoxic and anticancer activity $[12,33]$. Hence decreased level of haemoglobin $(\mathrm{Hb})$ in the experimental animals fed different concentrations of the ether and ethanol extracts of the plant may probably be due to the rapid haemolysis leading to haemolytic anaemia, reduction in level of haemoglobin $(\mathrm{Hb})$ which is a protein utilize by red blood cells for distribution of oxygen to other cells throughout the body [34]. The increase in the white blood cell counts and neutrophils encountered in experimental animals is a normal physiological response following perception of foreign attack by the body defence mechanisms.

At the end of week two of the experiment there was a significant decrease in glucose in and cholesterol in the three groups fed ethanol extracts of the plant $(p<0.05)$. On the other hand, there was a significant increase in the LDH concentration. This may possibly be explained by the damage which may have occurred in the liver hepatocytes.

Similarly, rats that fed ether extract showed significance decrease in glucose in all groups and there was also a significant decrease in cholesterol and triglycerides in animals fed 200 and 400. There was also significant increase in bilirubin concentration in groups fed 400, $600 \mathrm{mg} / \mathrm{kg} / \mathrm{bw}$. Injury to the liver, kidney and intestines may have probably contributed to elevation of bilirubin and creatinine concentrations. Hypocholesterolaemia and hypertriglyceridemia which have occurred during the experiment could possibly be due to interference of plant 
extracts with excretory ability of the liver cells. Similar results such as increase in the concentrations of ALP, ALT, creatinine and bilirubin in goats when studying the toxicity of Commiphora myrrha in goat kids fed 5 gm plant resin $/ \mathrm{kg} / \mathrm{d}$ and when the ethanol extract was orally given to rats daily for 2 weeks at $1000 \mathrm{mg} / \mathrm{kg}$ bw, $500 \mathrm{mg} / \mathrm{kg}$ bw or $250 \mathrm{mg} / \mathrm{kg}$ bw [28].

Both plant extracts used in the present study have hypolidiaemic (hypercholesterolemia and hypertriglyceridemia) as well as hypoglycaemic effects. It is possibly that both extracts of the plant contains agents such as guggulsterone which may have resulted into the decrease in the serum concentrations of glucose and lipids. Sharma et al. reported similar effect of guggulsterone (isolated from Commiphora mukul resin) and they suggested that guggulsterone has both hypoglycaemic and hypolipidemic effect which can help to cure type II diabetes [35]. Khalili reported similar results in diabetic rats which were fed $C$. mukul for extended periods and reported decrease in the values of serum glucose and the lipid profiles confirming the findings reported in the present study [36].

\section{Acknowledgement}

This research project was supported by a grant from the "Research Center of the Female Scientific and Medical Colleges", Deanship of Scientific Research, King Saud University.

\section{References}

1. Su SL, Duan JA, Tang YP, Zhang X, Yu L, Jiang FR, Zhou W, Luo D, Ding AW. Isolation and biological activities of neomyrrhaol and other terpenes from the resin of Commiphora myrrha. Plata Med 2009; 75: 351-355.

2. Vollesen KB. Flora of Ethiopia. National Herbarium, Addis Abeba University, Addis Abeba and Uppsala University, Uppsala 1989; 3: 442-478.

3. Baser KHC, Demirci B, Dekebo A, Dagne E. Essential oils of some Boswellia spp., Myrrh and Opopanax. Flav Fragr J 2003; 18: 153-156.

4. Steyn M. Southern Africa Commiphora. United Litho South Africa 2003; 39.

5. EI Ashry ES, Rashed N, Salama OM, Saleh A. Components, therapeutic value and uses of myrrh. Pharmazie 2003; 58: 163-168.

6. Massoud A, El Sisi S, Salama O. Preliminary study of therapeutic efficacy of a new fasciolicidal drug derived from Commiphora molmol (myrrh). Am J Trop Med Hyg 2001; 65: 96-99.

7. Satyavati GV, Dwarakanath C, Tripathi SN. Experimental studies on the hypocholesterolaemic effect of Commiphora mukul (guggul). Indian. J Med Res 1969; 57: 1950 .

8. Tarig M, Al-Yahya MA,. Mossa JS, Al-Meshal IA, AlBadr AA. Phytochemical, pharmacognostical and pharmacological studies on CNS depressant plants of Saudi Arabia. Proceedings the 4th International Congress of Pharmaceutical Science, (ICPS '85), Montreal, Canada $1985 ; 122$.

9. Shen T, Lou HX. Chemical constituents from resin of Commiphora species and their biological activities. Nat Prod Res Dev 2008; 20: 360-366.

10. Su SL, Duan JA, Wang TJ. Distribution, chemical components and bioactivity of resin herbs: research advances. J Int Pharm Res 2008; 36: 109-114.

11. Zhu NQ, Sheng SQ, Sang SM. Isolation and characterization of several aromatic sesquiterpenes from Commiphora myrrha. Flav Frag J 2003; 18: 282-285.

12. Al-Harbi MM, Qureshi S, Ahmed MM, Rafatullah S, Shah AH. Effect of Commiphora molmol (aloe-gumresin) on cytological and chemical changes induced by cyclophosphamide in mice. Am J Chinese Med 1994; 32: 77-82.

13. Hanus LO, Rezanka T, Dembitsky VM, Moussaieff A. Myrrh-Commiphora chemistry. Biomed Pap Med Fac Univ Palacky Olomouc Czech Repub 2005; 149: 3-27.

14. Provan GJ, Waterman PG. Major triterpenes from the resins of Commiphora incise. Phytochemistry 1988; 27: 3841-3843.

15. Shen T, Wan WZ, Yuan HQ, Kong F, Guo HF, Fan PH, Lou HX. Secondary metabolites from Commiphora opobalsamum and their antiproliferative effect on human prostate cancer cells. Phytochemistry 2007; 68: 1331-1337.

16. Avlessi F, Alitonou GA, Sohounhloue DK, Bessiere, JM, Menut C. Aromatic plants of tropical West Africa. Part XV. Chemical and biological evaluation of leaf essential oil of Commiphora Africana from Benin. J Essen Oil Res 2005; 17: 569-571.

17. Lukas AH, Christoph G, Michael VT, Friedrich N. Role of the vaginally administered aromatase inhibitor anastrozole in women with rectovaginal endometriosis: a pilot study. Fertil Steril 2005; 84: 1033- 1036.

18. Massoud AM, El Ebiary FH, Abou-Gamra MM, Mohamed GF, Shaker SM. Evaluation of schistosomicidal activity of myrrh extract: parasitological and histological study. J Egypt Soc Parasitol 2004; 34: 1051-1076.

19. Nomicos EY. Myrrh: medical marvel or myth of the Magi? Holist Nurs Pract 2007; 21: 308-323.

20. Omar A, Elmesallamy GS, Eassa S. Comparative study of the hepatotoxic, genotoxic and carcinogenic effects of praziquantel distocide and the natural myrrh extract Mirazid on adult male albino rats. J Egypt Soc Parasitol 2005; 35: 313-329.

21. Lis-Balchin M, Deans SG. Bioactivity of selected plant essential oils against Listeria monocytogenes. J Appl Bacteriol 1997; 82: 759-762.

22. Omer SA, Adam SEI, Mohammed OB. Antimicrobial activity of Commiphora myrrha against some bacteria and Candida albicans isolated from gazelles at King Khalid Wildlife research centre. Res J Med Plants 2011; 5: 65-75. 


\section{Saudi Arabia}

23. Reynolds JEF. Martindale the extra pharmacopoeia. Royal Pharma Soc, London 1996.

24. Bakari G, Max R, Mdegela R, Phiri E, Mtambo M. Antiviral activity of crude extracts from Commiphora swynnertonii against Newcastle disease virus in ovo. Tropical Anim Health Produc 2012; 44: 1389-1393.

25. Ji K, Kong F, Shen T. Separation and identification of myrrh sesquiterpenoids and their anti-proliferation effect on tumor cells. J. Shandong Univ (Health Sciences) 2008; 46: 344-348.

26. Li SY, Tian BC, Zhang YG, Wand HL, Jing LL, Mo XM. In vitro anti-proliferation effect of myrrh oil on rats' neuroglioma cells. Chin Trad Herb Dr 2009; 40: 1103-1106.

27. Wu WL, Liang ZQ. Aspirin's anti-proliferation effect on U251 cell in vitro and its mechanism. Chin Pharm Bull 2009; 25: 805-808.

28. Omer SA, Adam SEI, Khalid HE. Effects on rats of Commiphora myrrha extract given by different routes of administration. Vet Hum Toxicol 1999; 41: 193-196.

29. Sunday RM, Ilesanmi OR, Obuotor EM. Acute and subacute toxicity of aqueous extract of Abrus Precatorius seed in Wistar rats. Inter J Pharmacol 2013; 8: 67-72.

30. Pagana KD, Pagana TJ. Mosby's diagnostic and laboratory test reference. Mosby, St. Louis, USA 1997.

31. Al-Harbi MM, Qureshi S, Raza M, Ahmed MM, Afzal M, Shah A. Gastric anti-ulcer and cytoprotective effect of Commiphora molmol in rats. J Ethnopharmacol 1997; 55: 141-150.

32. Conning DM. Experimental toxicology. The Basic Issues 1993; 1-3.
33. Su S, Wang T, Chen T, Duan J, Yu L, Tang Y. Cytotoxicity activity of extracts and compounds from Commiphora myrrha resin against human gynecologic cancer cells. J Med Plants Res 2011; 5: 1382-1389.

34. Kumar G, Karthik L, Venkata K. Rao B. Haemolytic activity of Indian medicinal plants toward human erythrocytes: an in vitro study. Appl Botany 2011; 40: 5534-5537.

35. Sharma B, Salunke R, Srivastava S, Majumder C, Roy P. Effects of guggulsterone isolated from Commiphora mukul in high fat diet induced diabetic rats. Food Chem Toxicol 2009; 47: 2631-2639.

36. Khalili M, Vaez Mahdavi MR, Kiasalari Z, Ansari F. The effect of long-term consumption of Commiphora mukul feeding on the serum levels of glucose and lipids of diabetic rats. Iran J Endocr Metab 2009; 11: 71-77.

\section{*Correspondence to}

Sawsan A Omer

Department of Zoology

College of Science

King Saud University

University Centre for Women Students

Riyadh

Saudi Arabia

E-mail: sawsanaomer@gmail.com 